\title{
Bark, a suitable biosorbent for the removal of uranium from wastewater - From laboratory to industry
}

\author{
L. JAUBERTY ${ }^{1,2}$, V. GLOAGUEN ${ }^{1}$, C. ASTIER ${ }^{1}$, P. KRAUSZ ${ }^{1}$, V. DELPECH ${ }^{1,2}$,

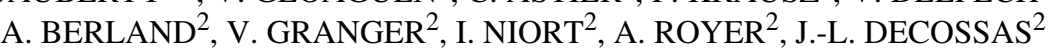

(Manuscript received 17 December 2010, accepted 26 May 2011)

ABSTRACT This paper shows that natural materials such as barks can successfully replace synthetic resins for industrial purposes. Evaluated in batch conditions, biosorption of uranium on suitably prepared Douglas fir barks took place in less than $10 \mathrm{~min}$ and appeared to be optimum at $\mathbf{p H}>4$. The biosorption process of uranium (uranyl form $\mathrm{UO}_{2}{ }^{2+}$ ) was characterized in the optimal physico-chemical conditions and could be mathematically modeled as a Langmuir isotherm. With a maximum uranium specific uptake $q_{\max }$ value of 1.16 meq.g ${ }^{-1}\left(138 \mathrm{mgU}^{-1} \mathrm{~g}^{-1}\right)$ it was found that the sorption capability of Douglas fir barks was at least five times higher for uranium than for other heavy metals such as lead. Adsorption of uranium contained in water leached from a former uranium mine was then monitored over a one-month period in a laboratory-scale chromatography column. The fixation capacity remained fairly constant throughout the whole testing period. Water radioactivity decreased from $1500 \mathrm{mBq} . \mathrm{L}^{-1}\left(0.12 \mathrm{mgU} . \mathrm{L}^{-1}\right)$ to $<5 \mathrm{mBq} . \mathrm{L}^{-1}\left(0.4 \mu \mathrm{gU} . \mathrm{L}^{-1}\right)$ at the column exit. This technology was successfully transferred and tested through a pilot project under industrial conditions with the support of AREVA NC.

Keywords: Uranium / biosorption / water treatment / barks

RÉSUMÉ Résorption de l'uranium par les écorces - De l'idée de laboratoire à son industrialisation.

Cet article montre que des matériaux naturels tels que les écorces peuvent efficacement remplacer des résines synthétiques dans des procédés industriels. Étudiée dans des conditions batch, la biosorption de l'uranium sur des écorces de sapin de Douglas préalablement préparées a lieu en moins de 10 minutes et est optimale pour des valeurs de $\mathrm{pH}$ supérieures à 4 . Le processus de biosorption de l'uranium $\left(\mathrm{UO}_{2}{ }^{2+}\right)$ a été caractérisé aux conditions physicochimiques optimales et a été modélisé par la théorie des isothermes de Langmuir. Avec une capacité d'adsorption maximale de l'uranium $q_{\max }$ égale à $1,16 \mathrm{meq.g}{ }^{-1}\left(138 \mathrm{mgU}^{-1}{ }^{-1}\right)$, la capacité de biosorption des écorces de sapin de Douglas est au moins cinq fois plus élevée pour l'uranium que pour d'autres métaux lourds comme le plomb. L'adsorption de l'uranium contenu dans l'eau d'exhaure d'une ancienne mine d'uranium a ensuite été réalisée au cours d'une période d'un mois dans une colonne de chromatographie en condition de laboratoire. La capacité d'adsorption du dispositif est restée constante tout au long de l'expérience. La radioactivité dans

Laboratoire de Chimie des Substances Naturelles EA1069, Faculté des Sciences et Techniques,

23 avenue Albert Thomas, 87060 Limoges, France.

2 Pe@rL SAS, 83 rue d'Isle, 87000 Limoges, France. 
l'eau a été divisée par un facteur supérieur à 300 , passant de $1500 \mathrm{mBq} \cdot \mathrm{L}^{-1}$ $\left(0,12 \mathrm{mgU} . \mathrm{L}^{-1}\right)$ en entrée de colonne à $<5 \mathrm{mBq} . \mathrm{L}^{-1}\left(<0,4 \mu \mathrm{gU} . \mathrm{L}^{-1}\right)$ en sortie de colonne. Le procédé a été transféré avec succès. Il est actuellement en phase de préindustrialisation sur un ancien site minier de la société AREVA NC.

\section{Introduction}

Heavy metal pollution by industrial wastewaters is a matter of environmental and public health concern. Removal of these metals represents a technological challenge that is being addressed by the development of innovative separation technologies (Schneider and Rubio, 1995). Various processes such as chemical precipitation, coagulation, solvent extraction, electrolysis, membrane separation, ion exchange and adsorption are commonly used to solve most of the heavy metal pollution problems. Among these processes, synthetic ion exchange resins and adsorption on activated charcoal are the most efficient methods but they necessitate high installation as well as regeneration costs. Moreover, due to the specifications of effluent treatments, application of such processes is sometimes restricted and often expensive (Jansson-Charrier et al., 1995).

Thus, new processes are emerging, as a consequence of the enforcement of legislation regulating wastewaters. In this context, biosorption using biologicallybased technologies has received some attention. This technique takes advantage of the binding capacities of various biological materials for inorganic pollutants, e.g. heavy metals from soil or wastewaters (Volesky, 1986). This technique is promising for the treatment or pre-treatment of industrial waste streams and natural waters and presents an alternative to conventional processes for the removal of metal ions, such as ion exchange on synthetic resins. Not only is biosorption a cost-effective tool for wastewater treatment, but it could also lead to new outlets for forestry (Seki et al., 1997; Aoyama et al., 1991) or agricultural (Waiss et al., 1973) by-products. It has been expected that advantage could be taken of the strong adsorption capacities displayed by barks, a low-cost and abundant forest by-product, in order to remove heavy metal ions from water effluents (Seki et al., 1997). This ability has been attributed to bark pectin and tannin, and more precisely to their respective carboxylic and phenolic groups which can bind metallic cations (Aoyama et al., 1993; Kumar and Dara, 1980).

The ability of barks to remove heavy metal ions from polluted solutions (Al-Asheh et al., 1998; Gaballah et al., 1997; Gloaguen et al., 1997; Seki et al., 1997; Aoyama et al., 1993; Deshkar et al., 1990; Kumar et al., 1980; Randall et al., 1974) and the impact of various operating factors on this phenomenon (Deshkar et al. , 1990) are well documented. In one of our precedent papers, these interactions were modeled using a Langmuir isotherm (Martin-Dupont et al., 2002) and 
adsorbent performances were improved using chemical modification by attachment of anionic functions (Martin-Dupont et al., 2004). This article aims to demonstrate the high stability of coniferous barks that should be considered not only as an additional biosorbent but also as an adsorption resin from a biological origin.

First of all, we studied the influence of $\mathrm{pH}$ and incubation time on uranium adsorption on Douglas fir barks. Langmuir isotherm parameters characterizing uranium adsorption were then determined from analysis of equilibrium binding data. Lastly, these experiments were repeated with natural water leached from a former uranium mining area as a model, first in batch conditions and then by percolation through a Douglas bark-filled chromatographic column; this last process was eventually scaled up to industrial working size.

\section{Material and methods}

\subsection{Material}

Douglas fir barks were obtained from a local sawmill located in the Limousin region (France). Two particle sizes were chosen: particles smaller than $200 \mu \mathrm{m}$ for batch studies and particles between 1 and $4 \mathrm{~mm}$ for column and industrial processes. Small-sized particles $(<200 \mu \mathrm{m})$ were used in laboratory conditions in order to increase the surface area in contact with solutions. Larger particles (1 to $4 \mathrm{~mm}$ ) were chosen for the scaled-up process in order to reduce the risk of column clogging. Barks were air-dried at $40{ }^{\circ} \mathrm{C}$ for $48 \mathrm{~h}$ and stored for further use in adsorption experiments.

\subsection{Chemicals}

All chemicals were of commercial grade of the highest available purity and were used without further purification. Milli-Q deionized water (Millipore system) was used throughout all experiments.

\subsection{Quantification of uranium by $U V$-visible spectrometry}

Quantification of uranium in solution was adapted from the arsezano-III methodology proposed by Haleem Khan et al. (2006). Reagent was prepared by dissolving $70 \mathrm{mg}$ of 2,7-bis(2-arsenophenylazo)-1,8-dihydroxynaphthalene-3,6disulfonic acid disodium salt (aka arsenazo-III) into 1 liter of $3 \mathrm{M}$ perchloric acid. One milliliter of raw or diluted extract was mixed with $4 \mathrm{~mL}$ of reagent. Absorbance was measured at $651 \mathrm{~nm}$ with a UV-visible 1700 Shimadzu spectrophotometer. Concentrations of uranium were deduced by comparison with a scale of uranyl nitrate accounting for 1 to $15 \mathrm{mg} \mathrm{U} . \mathrm{L}^{-1}$. Measurements were performed in triplicate. 


\subsection{Quantification of uranium by alpha and gamma spectrometry}

\subsubsection{Alpha spectrometry}

Samples of water were first acidified to $\mathrm{pH} 1$ and then treated according to NF M60805-5 standard (AFNOR, 2005). A known amount of a solution of uranium 232 with known activity (tracer) was added at the beginning of the chemical treatment. Pre-concentration of uranium from the acidified aqueous samples ( $\mathrm{pH} 1)$ was performed by co-precipitation with iron (III) hydroxide which was done by raising $\mathrm{pH}$ to 9 with ammonium hydroxide and further addition of a $10 \%$ iron (III) chloride solution. The precipitate containing the actinides was separated from the sample by centrifugation, and then dissolved in $6 \mathrm{M} \mathrm{HCl}$. Iron was extracted with diisopropylether using a separating funnel. Separation of uranium from the other actinides was done by ion-exchange chromatography in a glass column ( $\varnothing 15 \mathrm{~mm})$ filled with $10 \mathrm{~mL}$ of Dowex $1 \times 8$ (100-200 mesh) equilibrated with $8 \mathrm{M} \mathrm{HCl}$. Uranium-containing solutions were dried, re-dissolved in $50 \mathrm{~mL}$ of $8 \mathrm{M} \mathrm{HCl}$ and passed through the column. The uranium fraction was eluted with an equal volume of $0.1 \mathrm{M} \mathrm{HCl}$. Purified uranium was extracted from this fraction with toluenesaturated 2-thenoyltrifluoroacetone (TTA). Extracts were deposited on small aluminum dishes and dried before counting. Samples were counted for alphas using PIPS detectors in vacuum chambers (CANBERRA ALPHA 4). Detectors were coupled to low noise pre-amplifiers, amplifiers and a multichannel analyzer. Spectra were collected over a time sufficient to obtain 1000 counts. Uranium concentration was determined by comparison between the signal corresponding to ${ }^{232} \mathrm{U}$ and those from ${ }^{238} \mathrm{U}$ and ${ }^{234} \mathrm{U}$ natural isotopes.

\subsubsection{Gamma spectrometry}

Natural isotopes of uranium are not easily measured by means of gamma spectrometry. Regarding uranium 238, an indirect method consists of measuring thorium 234 activity. Since the period of the latter is 24.1 days, repeated measurements spaced out at several-week intervals are required to extrapolate the thorium regrowth curve at time zero and to calculate the initial uranium concentration with maximum precision. Samples to be measured were crushed down to particle size smaller than $200 \mu \mathrm{m}$ and were placed in a hermetic tube fitted into the Ge detector chamber (CANBERRA EGPC 300P).

\subsection{Uranium adsorption on barks}

Adsorption studies were carried out in batch conditions by adding $50 \mathrm{mg}$ of ground barks (particle size $<200 \mu \mathrm{m}$ ) to $50 \mathrm{~mL}$ of uranium aqueous solutions prepared from uranyl acetate. Suspensions were shaken at room temperature and the 
adsorbent was finally separated from the solution by vacuum filtration through a sintered glass filter (porosity 3). The residual concentration of uranium in solution was determined by the arsenazo-III method.

\subsubsection{Influence of $\mathrm{pH}$}

The initial concentration of uranium was $10 \mathrm{mg} . \mathrm{L}^{-1}$, and $\mathrm{pH}$ varied from 1 to 6 ; suspensions were shaken at room temperature for 2 hours to ensure equilibrium.

\subsubsection{Influence of uranium concentration}

The initial uranium concentration varied from 0 to $400 \mathrm{mg} \cdot \mathrm{L}^{-1}$ and $\mathrm{pH}$ was adjusted to 4 ; suspensions were shaken at room temperature for $2 \mathrm{~h}$ to ensure equilibrium.

\subsubsection{Kinetic studies}

The initial concentration of uranium was $20 \mathrm{mg} . \mathrm{L}^{-1}$ and $\mathrm{pH}$ was adjusted to 4 ; bark suspensions were shaken at room temperature for contact time periods varying from 1 to $120 \mathrm{~min}$.

\subsection{Study of the sorption process from natural waters in batch conditions}

Two liters of water leached from a former uranium mine (average uranium concentration: $100 \mu \mathrm{g} . \mathrm{L}^{-1}$ ) were tested without additional treatment or after a $0.45-\mu \mathrm{m}$ filtration to evaluate, respectively, the adsorption of total uranium or the soluble uranium fraction. Barks $(1 \mathrm{~g})$ were shaken for 2 hours in one liter of each of these two types of waters with preliminary $\mathrm{pH}$ adjusted to 4 . Barks were separated from the solution by vacuum filtration through a sintered glass filter (porosity 3). The initial and residual concentrations of uranium in the solution were determined by alpha spectrometry and the amounts adsorbed on barks by gamma spectrometry.

\subsection{Desorption tests}

At room temperature, 1 gram of uranium-loaded bark was brought into contact with 0.01 to $1 \mathrm{~mol} . \mathrm{L}^{-1}$ sulfuric acid solutions for 1 hour under magnetic stirring. Barks were then separated from the solution by vacuum filtration through a sintered glass filter (porosity 3 ). Uranium concentration was determined by the arsenazo-III method. 


\subsection{Chromatographic development}

Douglas barks were washed in deionized water for about $15 \mathrm{~min}$ and air-dried. A glass column (Ø: $38 \mathrm{~mm}$; h: $30 \mathrm{~cm}$ ) was filled with 60 grams of ground barks (particle size 1 to $4 \mathrm{~mm}$ ). Glass beads were placed on the top of the column in order to avoid bed disturbance. Natural water $\left(0.5 \mathrm{~L} . d a y^{-1}\right)$ was delivered by a peristaltic pump. Every week, uranium concentrations were measured in inflow and eluate samples by alpha spectrometry. After 4 weeks, the column was rinsed with $500 \mathrm{~mL}$ of ultrapure water, and barks were removed from the column before quantification of adsorbed uranium by gamma spectrometry.

\subsection{Scaling up of the process}

The pilot plant consisted of four plastic columns (Ø: $25 \mathrm{~cm}$; h: $100 \mathrm{~cm}$ ), each one with a maximal capacity of $10 \mathrm{~kg}$ bark (particle size 1 to $4 \mathrm{~mm}$ ). For this experiment, one of these columns was used and the flow rate of natural water from another former uranium mine site $\left(200 \mathrm{~L} .^{-1}\right)$ was maintained by a peristaltic pump (average uranium concentration: $550 \mu \mathrm{g} . \mathrm{L}^{-1}$ ). Every hour, the uranium concentration in the column eluate was determined by alpha spectrometry. Water percolation was continued for five hours (total volume $1 \mathrm{~m}^{3}$ ). The column was rinsed with tap water and barks were unloaded by removing successive 10 -cm-thick layers which were individually processed and subjected to uranium quantification by gamma spectrometry.

\section{Results and discussion}

\subsection{Equilibrium studies of sorption process}

\subsubsection{Influence of $p H$}

Adsorption of uranium on barks appears to be a pH-dependent phenomenon (Fig. 1) and is explained by uranium speciation. For acidic $\mathrm{pH}$ values $(1<\mathrm{pH}<2)$, adsorption of uranium was minimal: although the prevailing species of uranium is $\mathrm{UO}_{2}{ }^{+}$, its adsorption is counteracted by protons which present a higher affinity for bark adsorption sites, and whose concentration is also somewhat higher than uranium. At $2<\mathrm{pH}<4$ uranium adsorption increases very significantly and reaches a maximum at $\mathrm{pH} 4$, where proton competition is much less significant. The plateau observed between $\mathrm{pH} 4$ and 5 indicates that, within this $\mathrm{pH}$ interval, the interacting species are not influenced by $\mathrm{pH}$; for instance, predominant $\mathrm{UO}_{2}{ }^{2+}$ species and, most probably, the carboxylate groups of wood pectin. For higher $\mathrm{pH}$ values, the slight increase in adsorption could probably be explained by the formation of insoluble uranium species. 


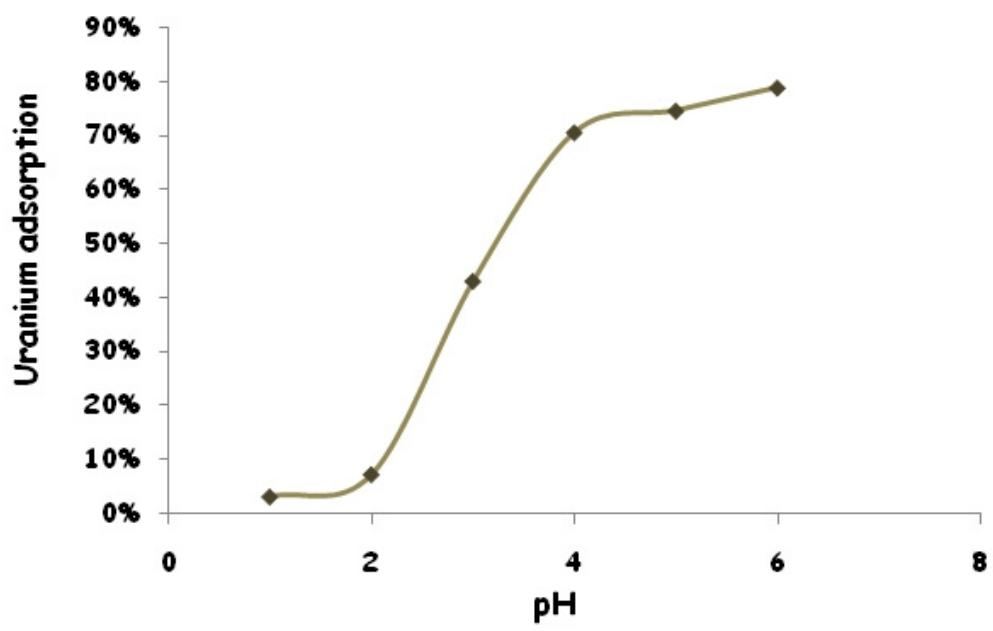

Figure 1 - Influence of $\mathrm{pH}$ on uranium adsorption on barks.

Influence du $\mathrm{pH}$ sur l'adsorption de l'uranium par les écorces.

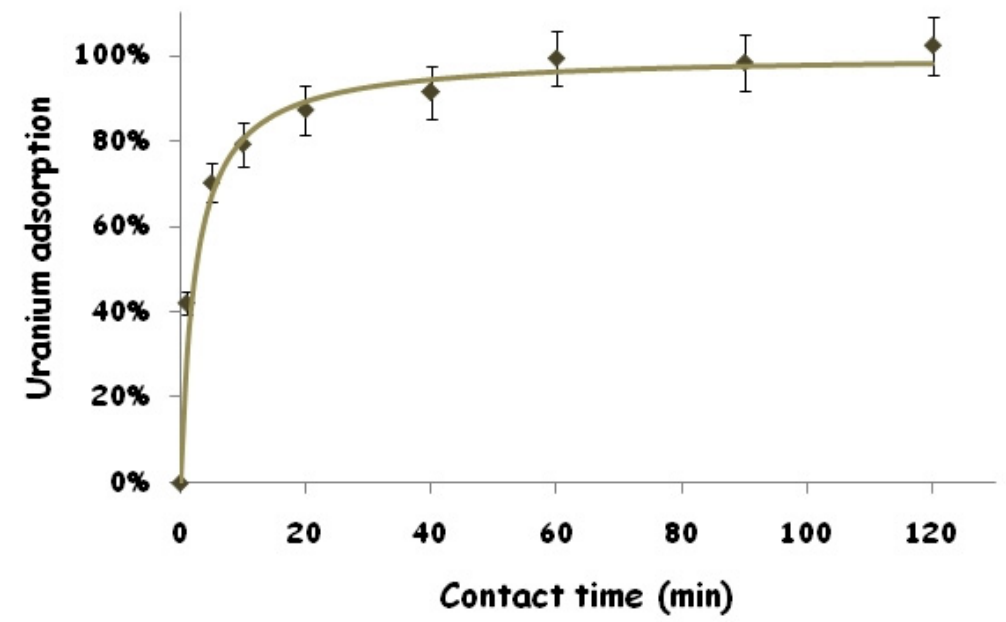

Figure 2 - Influence of contact time on uranium adsorption on barks.

Influence du temps de contact sur l'adsorption de l'uranium par les écorces.

\subsubsection{Kinetic study}

The kinetic study of adsorption of uranium on barks is presented in Figure 2. Adsorption of uranium on barks is quite rapid since up to $80 \%$ of the uranium is adsorbed after only 10 minutes of contact. Equilibrium is reached after 60 minutes. 


\subsubsection{Adsorption isotherms and Langmuir modeling}

Adsorption isotherms constitute a good approach to appreciate the specific metal uptake value $(q)$, which could be determined by the following relation (Veglio et al., 1997):

$$
q=\frac{\left(C_{o}-C_{e q}\right)}{X}
$$

where $q$ is the metal specific uptake per unit weight of barks (meq.g ${ }^{-1}$ ) at the equilibrium concentration $C_{e q}$ (meq. $\mathrm{L}^{-1}$ ) in the aqueous solution phase, $C_{o}$ is the initial metal concentration (meq. $\left.\mathrm{L}^{-1}\right)$ and $X\left(\mathrm{~g} . \mathrm{L}^{-1}\right)$ is the bark concentration in solution.

The Langmuir adsorption model (Al-Asheh et al., 1998) is usually used to characterize quantitative and qualitative aspects of the interaction between metal ions and barks and it gives the advantage of being able to predict bark saturation. The Langmuir model is only limited by the following four postulates (Adamson, 1976; Weber, 1972): (a) the adsorption sites are evenly distributed on the bark surface, (b) there is a stoichiometric interaction between one metal ion and one adsorption site, (c) equilibrium leads to the formation of a monolayer, and (d) adsorption of one metal ion on one site is independent of the binding state of the surrounding ones. The Langmuir equation is described as follows (Desjardins, 1988):

$$
q=\frac{q_{\max } \cdot b \cdot C_{e q}}{1+b \cdot C_{e q}}
$$

where $q_{\text {max }}$ (meq. ${ }^{-1}$ ) is the maximum metal specific uptake, $b$ (L.meq $\left.{ }^{-1}\right)$ is the Langmuir constant, and $C_{e q}$ (meq. $\mathrm{L}^{-1}$ ) is the metal equilibrium concentration in the aqueous phase. Such parameters are of high importance since they provide valuable information that could contribute to improving our understanding of metal uptake mechanisms onto barks. The $b$ parameter is related to the energy of adsorption. Furthermore, from the initial linear part of the isotherm, the $b$ value is a direct function of the dissociation constant $K_{d}$ and therefore characterizes the affinity of the solute for the sorbent. The $q_{\max }$ and $b$ parameters were readily obtained from experimental data by plotting Equation (3) in the following double reciprocal form:

$$
\frac{1}{q}=\frac{1}{q_{\max } \cdot b \cdot C_{e q}}+\frac{1}{q_{\max }} .
$$

The interaction between barks and uranyl solutions was studied and modeled through the Langmuir isotherm methodology (Fig. 3a). In this case, room temperature as well as a $\mathrm{pH}$ value of 4 and a 2-h contact time were chosen as 

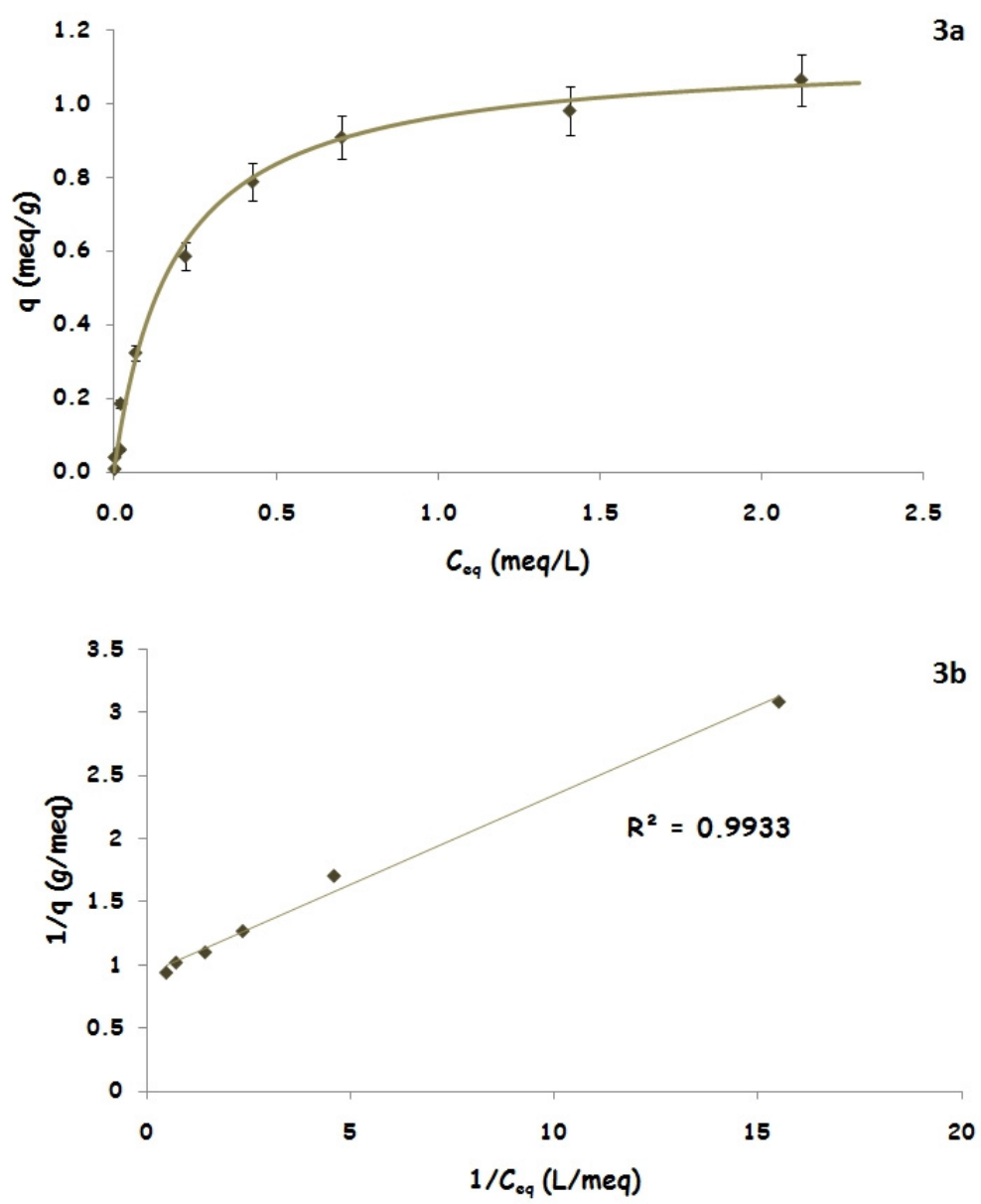

Figure 3 - Adsorption isotherm of uranium on barks (3a) and its linearization (3b).

Isotherme d'adsorption de l'uranium par les écorces (3a) et sa linéarisation (3b).

standard conditions of the experiments. The Langmuir parameters, $q_{\max }$ and $b$, were then graphically determined from Figure $3 b$ after linearization of the isotherm. The correlation coefficient $r^{2}>0.99$ proves that the Langmuir model is well adapted for this study. With a $q_{\max }$ of 1.16 meq.g ${ }^{-1}\left(138 \mathrm{mgU}^{-1}{ }^{-1}\right)$ and a $b$

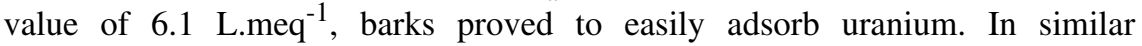
experimental conditions (Martin-Dupont et al., 2002), the uranium adsorption capability of Douglas fir barks appears to be at least five times that of lead, a common heavy metal with a charge similar to $\mathrm{UO}_{2}{ }^{2+}$ and a mass of $207 \mathrm{~g} \cdot \mathrm{mol}^{-1}$ 
TABLE I

Adsorption of uranium from natural water in batch conditions.

Adsorption de l'uranium à partir d'une eau naturelle en condition batch.

\begin{tabular}{lcccc}
\hline Experiment & \multicolumn{2}{c}{ Raw water } & \multicolumn{2}{c}{ Filtered water } \\
\hline Location & Water $\left(\mu \mathrm{g} . \mathrm{L}^{-1}\right)$ & Barks $\left(\mu \mathrm{g} \cdot \mathrm{g}^{-1}\right)$ & Water $\left(\mu \mathrm{g} \cdot \mathrm{L}^{-1}\right)$ & Barks $\left(\mu \mathrm{g} \cdot \mathrm{g}^{-1}\right)$ \\
$\begin{array}{l}\text { Uranium concentration before } \\
\text { contact }\end{array}$ & $111.0 \pm 4.0$ & $<0.2 *$ & $26.9 \pm 1.0$ & $<0.2 *$ \\
$\begin{array}{l}\text { Uranium concentration after } \\
\text { contact }\end{array}$ & $10.6 \pm 0.6$ & $88.8 \pm 9.7$ & $3.3 \pm 0.2$ & $21.5 \pm 3.4$ \\
\hline
\end{tabular}

* Values below detection threshold.

(270 g.mol ${ }^{-1}$ for $\left.\mathrm{UO}_{2}{ }^{2+}\right)$. With $q_{\max }=1.4 \mathrm{meq} \cdot \mathrm{g}^{-1}\left(166 \mathrm{mgU} \cdot \mathrm{g}^{-1}\right)$ and $b=$ 4.1 L.meq ${ }^{-1}$, the data obtained in our laboratory experimental conditions with Amberlite IR120, a common synthetic cation exchange resin, are similar.

\subsection{Study of the sorption process from natural water in laboratory conditions}

\subsubsection{Batch conditions}

With the aim of studying the adsorption of the soluble and insoluble uranium fractions from solutions, natural water drained from a former uranium mine was firstly tested in batch conditions. A set of experiments was realized with: (i) natural water (raw water-soluble and insoluble fractions of uranium), and (ii) water filtered through a $0.45-\mu \mathrm{m}$ filter (soluble fraction of uranium). The results presented in Table I show that in both cases $90 \%$ of the uranium was transferred to the barks. Barks are thus able to adsorb the soluble fraction of uranium and its particle or colloidal forms as well.

\subsubsection{Desorption tests}

Acidic desorption was studied on uranium-loaded bark in batch conditions. Desorption was induced by contact with various sulfuric acid solutions whose concentrations ranged from 0.01 to $1 \mathrm{~mol} . \mathrm{L}^{-1}$. Sulfuric acid was used in this case to obtain the synergistic effects of the action of protons and the chelating effect of the sulfate anion. From Figure 4, it could be assumed that increasing sulfuric acid concentration led to uranium removal from loaded bark. Reuse tests of barks over several cycles are presently under study. 


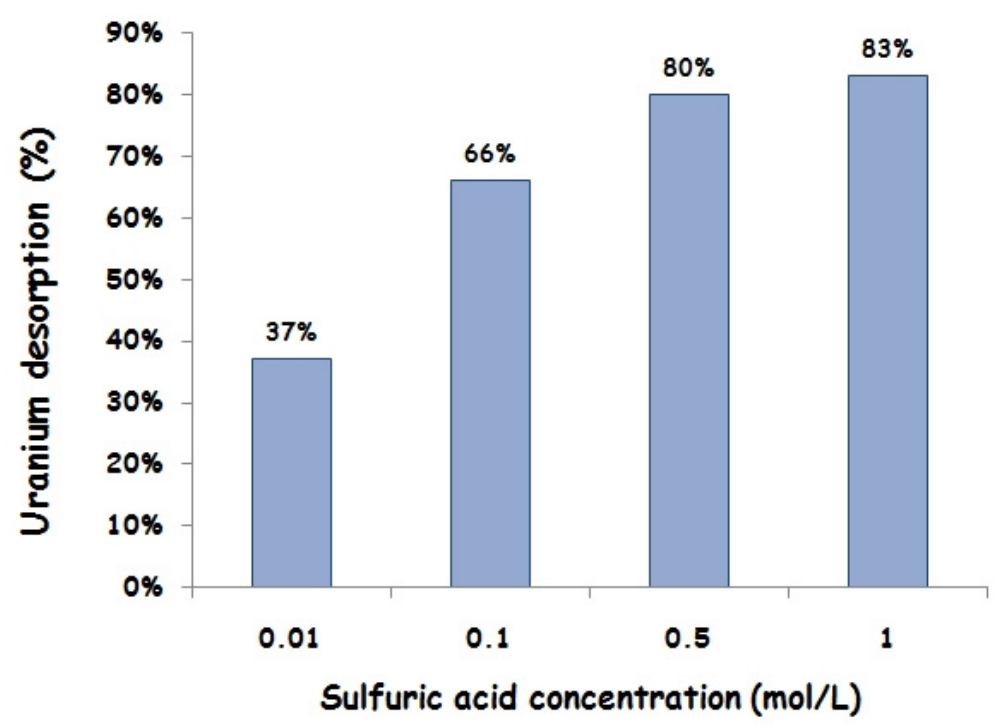

Figure 4 - Study of the desorption of uranium from loaded barks.

Étude de la désorption de l'uranium à partir d'écorces chargées en uranium.

\subsubsection{Continuous chromatography conditions}

To ensure the scaling up of the proposed technology, barks have to demonstrate their ability to be used in continuous chromatographic conditions. To this end, 14 liters of natural water leached from a former uranium mine were continuously filtered through a bark-loaded chromatography column ( week period. Once a week, uranium was measured in the mobile phase and in the eluate. From the results presented in Table II, it can be observed that barks are able to adsorb the total amount of uranium from water. In such experimental conditions, $1.3 \mathrm{mg}$ of uranium was adsorbed on $60 \mathrm{~g}$ of barks. Taking into account a typical maximum uranium specific uptake of barks $-q_{\max }=138 \mathrm{mgU} \cdot \mathrm{g}^{-1}$, this column could bind at least $8.3 \mathrm{~g}$ of uranium and would be theoretically able to treat more than $70 \mathrm{~m}^{3}$ of the natural water tested in this experiment.

\subsection{Scaling up of the process: from a few grams to a few kilograms}

Thanks to the support of the Pe@rL Company and to a grant from the "OSEO Innovation" institution, this technology was transferred and tested through a pilot project under industrial conditions with the support of AREVA NC. One thousand liters of natural water drained from former uranium mines with a ${ }^{238} \mathrm{U}$ activity of 
TABLE II

Adsorption of uranium from natural water in continuous chromatographic conditions. Adsorption de l'uranium à partir d'une eau naturelle en condition continue de chromatographie.

\begin{tabular}{ccc} 
Week & Sampling & {$[\mathbf{U}]\left(\boldsymbol{\mu g . L ^ { - 1 } )}\right.$} \\
\hline $\mathbf{1}$ & Top & $88.9 \pm 5.3$ \\
& Exit & $1.0 \pm 0.1$ \\
$\mathbf{2}$ & Top & $107.5 \pm 4.5$ \\
$\mathbf{3}$ & Exit & $0.1 \pm 0.1$ \\
& Top & $119.6 \pm 7.8$ \\
& Exit & $0.2 \pm 0.1$ \\
& Top & $115.9 \pm 8.6$ \\
& Exit & $0.3 \pm 0.1$ \\
\hline
\end{tabular}

7 Bq.L ${ }^{-1}\left(560 \mu \mathrm{g} . \mathrm{L}^{-1}\right.$ of uranium) were then percolated through a column packed with $10 \mathrm{~kg}$ of bark (see section 2.8) at a typical flow rate of $200 \mathrm{~L} . \mathrm{h}^{-1}$. During the experiment, the concentration of uranium in the eluate was measured every $200 \mathrm{~L}$. The amount of uranium adsorbed was then evaluated in each one of the $10-\mathrm{cm}$ sections of the bed. From Figure 5a, it can be observed that the activity of the water drastically decreased to less than $5 \mathrm{mBq} . \mathrm{L}^{-1}\left(0.4 \mu \mathrm{g} . \mathrm{L}^{-1}\right)$. The scaling up procedure does not seem to have any negative impact on the capacities of barks to adsorb uranium from natural water. In addition, it is interesting to note that uranium was virtually transferred onto the first $20-30 \mathrm{~cm}$ of the column (Fig. $5 \mathrm{~b}$ ).

Taking into account these new results, it is interesting to estimate the performance of the pilot. If we consider a system with specific characteristics such as:

- a natural water containing $400 \mu \mathrm{g}$ of uranium per liter;

- a typical $q_{\max }$ value of 138 milligrams of uranium per gram of barks;

- the use of a column filled with $10 \mathrm{~kg}$ of barks operating at a flow rate of 1000 L.h ${ }^{-1}$.

The theoretical treatment period could be estimated to be 150 days with at least $1.3 \mathrm{~kg}$ of uranium adsorbed.

\section{Conclusion}

Due to their high and stable exchange capacities as well as being cost-effective and environmentally friendly, the use of barks could really be considered as a secure and affordable way to achieve wastewater treatment operations. 

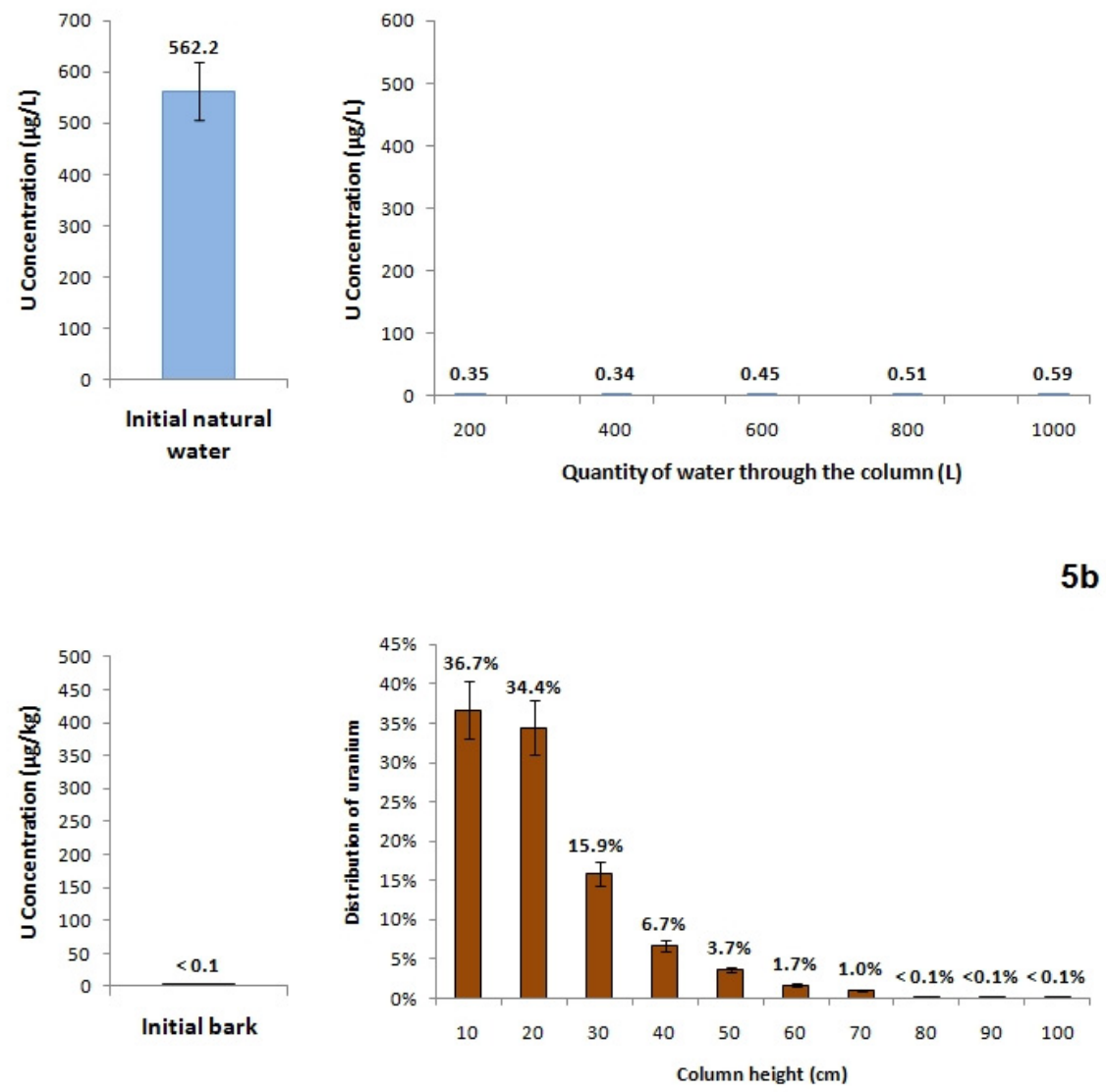

Figure 5 - Scaling up of the process: adsorption of uranium in pilot conditions. Uranium concentration of natural water at the top and the bottom of the column (5a) and on barks before and after the experiment (5b).

Dimensionnement à l'échelle pilote : résultats d'adsorption à l'échelle préindustrielle. Concentration en uranium dans l'eau naturelle à l'entrée et à la sortie du pilote (5a) et sur les écorces avant et après l'expérience $(5 b)$.

Acknowledgements. The authors gratefully acknowledge Dr. M. Guilloton for his help in manuscript editing, and the Conseil Régional du Limousin and the OSEO Innovation Institution for their financial support. 


\section{REFERENCES}

Adamson A.W. (1976) Physical chemistry of surfaces (J. Wiley \& Sons, Ed.) New York, 1.

AFNOR (2005) Mesure de la radioactivité dans l'environnement - eau : mesurage de l'activité et de la concentration de l'uranium dans l'eau par spectrométrie alpha.

Al-Asheh S., Duvnjak Z. (1998) Binary metal sorption by pine bark: study of equilibria and mechanisms, Separ. Sci. Technol. 33, 1303-1329.

Aoyama M., Honma S., Kasai A., Iseda Y., Nakajima A., Sakaguchi T. (1991) Uranium uptake by conifer leaves, Holzforschung 45, 75-77.

Aoyama M., Seki K., Sensho H., Kasai A. (1993) Adsorption of heavy metal ions by hardwood barks, Cellulose Chem. Technol. 27, 39-46.

Deshkar A.M., Bokade S.S., Dara S.S. (1990) Modified Hardwickia binata bark for adsorption of mercury (II) from water, Wat. Res. 24, 1011-1016.

Desjardins R. (1988) Le traitement des eaux (École Polytechnique de Montréal, Ed.) Montréal, 366.

Gaballah I., Goy D., Allain E., Kilbertus G., Thauront J. (1997) Recovery of copper through decontamination of synthetic solutions using modified barks, Metall. Mater. Trans. B 28, 13-23.

Gloaguen V., Morvan H. (1997) Removal of heavy ions from aqueous solution by modified barks, $J$. Environ. Sci. Health A 32, 901-912.

Haleem Khan M., Warwick P., Evans N. (2006) Spectrophotometric determination of uranium with arsenazo-III in perchloric acid, Chemosphere 63, 1165-1169.

Jansson-Charrier M., Guibal E., Surjous R., Le Cloirec P. (1995) Continuous removal of uranium by biosorption onto chitosan: application to an industrial effluent, in: Biohydrometallurgical processing (C.A. Jerez, T. Vargas, H. Toledo, J.V. Wiertz, Eds.) pp. 257-266, University of Chile, Santiago, Chile.

Kumar P., Dara S.S. (1980) Modified barks for scavenging toxic heavy metal ions, Ind. J. Environ. Health 22, 196-202.

Martin-Dupont F., Gloaguen V., Granet R., Guilloton M., Krausz P. (2004) Chemical modifications of Douglas fir bark, a lignocellulosic by-products - Enhancement of their lead (II) binding capacities, Separ. Sci. Technol. 39, 1-16.

Martin-Dupont F., Gloaguen V., Granet R., Guilloton M., Morvan H., Krausz P. (2002) Heavy metal adsorption by crude coniferous barks: a modeling study, J. Environ. Sci. Health A 37, 10631073.

Randall J., Berman R.L., Garrett V., Waiss A.C. (1974) Use of bark to remove metal ions from waste solutions, Forest Prod. 24, 80-84.

Schneider I.A.H., Rubio J. (1995) New trends in biosorption of heavy metals by freshwater macrophytes, in: Biohydrometallurgical processing (C.A. Jerez, T. Vargas, H. Toledo, J.V. Wiertz, Eds.) pp. 247-256, University of Chile, Santiago, Chile.

Seki K., Saito N., Aoyama M. (1997) Removal of heavy metal ions from solutions by coniferous barks, Wood Sci. Technol. 31, 441-447.

Veglio F., Beolchini F., Gasbarro A. (1997) Biosorption of toxic metals: an equilibrium study using free cells of Arthrobacter sp., Process Biochem. 32, 99-105.

Volesky B. (1986) Biosorbent materials, Biotechnol. Bioeng. Symp. 16, 121-126.

Waiss A.C. Jr., Wiley M.E., Kuhnle J.A., Potter A.L., McCready R.M. (1973) Adsorption of mercuric cation by tannins in agricultural residues, J. Environ. Qual. 2, 369-371.

Weber W.J.P. (1972) Physicochemical processes for water quality control (J. Wiley \& Sons, Ed.) New York, 200 